\title{
SIZE SELECTIVITY AND ENERGY MAXIMISATION OF THE INTRODUCED SEASTAR, ASTERIAS AMURENSIS (LÜTKEN), IN TASMANIA, AUSTRALIA
}

\author{
by S.J. Lockhart and D.A. Ritz \\ (with two tables and five text-figures)
}

LOCKharT, S.J. \& Ritz, D.A., 2001 (31:xii): Size selectivity and energy maximisation of the introduced seastar, Asterias amurensis (Liitken), in Tasmania, Australia. Pap. Proc. R. Soc. Tasm. 135: 35-40. https://doi.org/10.26749/rstpp.135.35 ISSN 0080-4703. Department of Ocean Sciences, University of California, Santa Cruz, USA (SJL); School of Zoology, University of Tasmania, GPO Box 252-5, Hobart, Tasmania, Australia 7001 (DAR).

\begin{abstract}
The selectivity of the introduced north Pacific seastar, Asterias amurensis, for different sizes of prey was investigated with the aim of predicting the impact this species will have on the age structure of native prey species and, thus, on their survival. The energy maximisation capabilities of $A$. amurensis were assessed. The time small $A$. amurensis $(\mathrm{r}=56-77 \mathrm{~mm})$ spent handling the mussel Mytilus edulis increased exponentially with increases in mussel size; handling time by large seastars $(\mathrm{r}=78-86 \mathrm{~mm})$ only increased when eating the largest mussels offered. Mussels of the size class 20-29 mm were preferred. The energy content of six mussel size classes was divided by the handling time of each to give a prey value. The optimal mussel size class was calculated to be 30-39 mm. Thus, $A$. amurensis was not shown to maximise its energy by consuming mussels of a size that would give the greatest energy return for the energy expended. Smaller seastars consumed a greater percentage of their body weights per day (4.97\%) than did larger seastars $(2.57 \%)$.
\end{abstract}

Key Words: Asterias amurensis, energy maximisation, introduced species, optimal foraging, seastar, size selectivity, Tasmania.

\section{INTRODUCTION}

The northern Pacific seastar, Asterias amurensis, has established itself in southeastern Tasmanian waters after being introduced, probably as larvae transported in the ballast waters of ships, sometime in the 1980s (Turner 1992, Buttermore et al. 1994, Morrice 1995, Byrne et al. 1997). It was first collected in 1986 but not correctly identified until 1991 (Turner 1992, Buttermore et al. 1994, Byrne et al. 1997). A. amurensis, is considered a major pest within its native range, preying on commercial scallops and a great variety of other benthic invertebrates (Hatanaka \& Kosaka 1959).

Predators often select the size of prey they eat. This behaviour can have important effects on the age structure and spatial distribution of a prey population (Landenberger 1968). There are a number of factors that affect the selection of various sized prey: ease of manipulation, available stomach area and maximal energy intake per unit time (McClintock \& Lawrence 1981, Beddingfield \& McClintock 1993). Seastars often show a preference for bivalves and gastropods which are significantly smaller than the mean size of those available (Christensen 1970, Doering 1981, McClintock \& Lawrence 1981, 1985, Beddingfield \& McClintock 1993). The maximum size in shell length eaten by the seastar $A$. amurensis, differs slightly according to the amount of food already in the predator's stomach and the quantity of suitably sized food found in the environment (Kim 1969). Even the largest seastar, Pycnopodia helianthoides, can maintain itself on small prey items (Paul \& Feder 1975). However, this is in contrast to the habits of the seastars Asterias rubens, Pisasterspp. and Leptasterias hexactis, where large size is dependent on a plentiful supply of large prey items (Larsson 1968 in Paul \& Feder 1975, Feder 1970, Menge 1972).

Size selectivity can be considered a process of optimal foraging, whereby different sizes of prey represent different prey values (energy content/handling time) to a predator.
The consumption of an optimal size (i.e. of greatest prey value) maximises the net energy gain for a predator. Hughes (1980) stated five rules involving the selection of prey of differing values by which, according to optimal foraging theory, a predator should forage. These are:

(1) a predator should consume the highest ranking prey;

(2) a predator should consume suboptimal prey when optimal prey are scarce;

(3) the highest ranking prey should always be consumed no matter how infrequently encountered;

(4) when recognition time is significant, lower ranking prey may be consumed if they are frequently encountered, even when optimal prey are plentiful;

(5) when recognition time is zero, lower ranking prey should never be consumed if optimal prey are plentiful.

Thedirect comparison of preyvalue curves with size frequency of prey in the diet has only been attempted in a few studies (Hughes 1980). To the authors' knowledge, no studies of this kind, focusing on asteroids, have previously been conducted.

This experiment is designed to investigate the selectivity of $A$. amurensis for different sizes of the mussel, Mytilus edulis, with the aim of predicting the impact this species will have on the age structure of native prey species. Also, in selecting particular prey sizes, the energy maximisation capabilities of $A$. amurensis can be assessed and thus, these results will help predict its success and impact in Tasmania.

\section{MATERIALS AND METHODS}

\section{Experimental Animals}

Seastars in each of two size classes were collected from both Nutgrove Beach and off the wharfs of the Derwent Sailing Squadron, Hobart $\left(147^{\circ} 20^{\prime} \mathrm{E}, 42^{\circ} 56^{\prime} \mathrm{N}\right)$. The small size class ranged from $56-77 \mathrm{~mm}$ (radius)(av. $63.4 \mathrm{~mm} \pm 6.5$ $\mathrm{SD}$ ) and the large size class ranged from $78-86 \mathrm{~mm}$ (av. $81.2 \mathrm{~mm} \pm 1.9 \mathrm{SD}$ ). Because of small sample sizes, both 
classes were combined in experiments to determine prey size selection and handling time. All mussels (Mytilus edulis) were collected from off the Derwent Sailing Squadron wharfs and were cleaned of barnacles. Each seastar was held in a separate aquarium, filled to a depth of $150 \mathrm{~mm}$ with fresh seawater, of salinity $33 \% \pm 2 \mathrm{SD}$, filtered through activated charcoal (EHEIM, 2213). Seastars were acclimatised at $12^{\circ} \mathrm{C}$ without food for $24 \mathrm{~h}$ before experiments began to standardise hunger levels.

\section{Handling Time}

Handling time was investigated using time lapse video (Panasonic, FS 90) to accommodate $24 \mathrm{~h}$ of filming onto a $4 \mathrm{~h}$ tape. The camera (Panasonic, WV BL 600) was directed at an aquarium separated into four compartments, each of which held a single seastar, two of each size class. Mussels of six size classes (i.e. $<10 \mathrm{~mm} ; 10-19 \mathrm{~mm} ; 20-29 \mathrm{~mm}$; $30-39 \mathrm{~mm}$; 40-49 mm; 50-59 mm; 60-69 mm) were presented to each of the four seastars in random order to reduce any bias due to the effect of accumulating satiation, and the following events were timed:

(1) Orientation Time (To). To was defined as the time from the seastar's first physical contact with the mussel, through the period of orientating the mussel into position for feeding, until the seastar ceased movement.

(2) Feeding Time (Tf). Tf was defined as the period from the end of To to the abandonment of the empty shell.

(3) Handling Time (Th). Th was defined as the sum of To and $T f$.

\section{Mussel Energy Content and Prey Value}

The energy of mussel flesh $(E)$ was measured in a microbomb calorimeter after the flesh from mussels of known shell length was dried for $24 \mathrm{~h}$ at $70^{\circ} \mathrm{C}$. The energy contents of five mussels in each size class were measured. With the

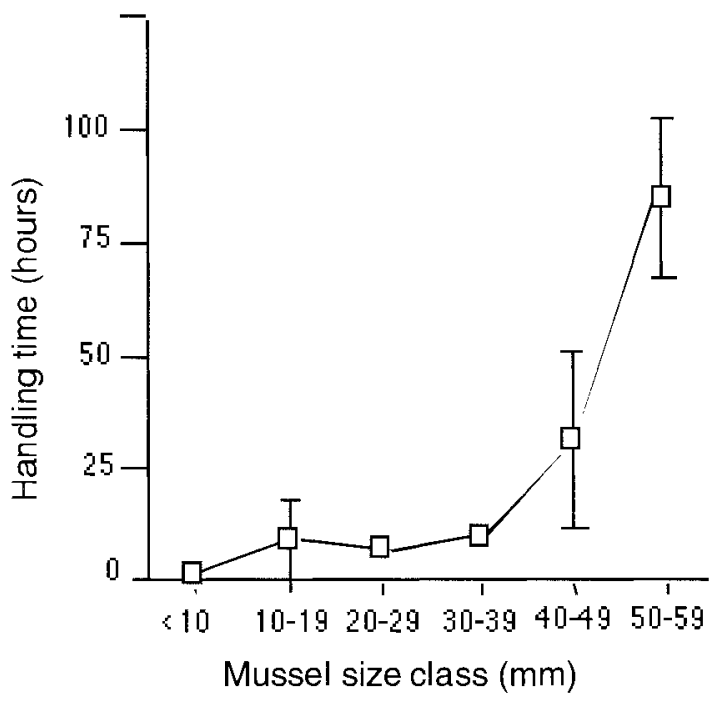

FIG. 1 - Handling times for the seastar Asterias amurensis feeding on a range of mussel size classes. exception of the two smallest mussel classes (for which the entire volume of flesh could be used), two subsamples were taken and averaged for each of these five mussels in each of the six size classes. To test for a variation in energy content between the different mussel size classes the results were subjected to a one-way ANOVA. The smallest mussel size class (i.e. $<10 \mathrm{~mm}$ ) was not included in this analysis.

Prey value was defined as E/Th. These definitions ignore any differences in the metabolic costs of the various handling activities.

\section{Size Selectivity}

Due to a lack of aquaria and space, all seastar sizes could not be tested at the same time. However, every effort was made to reproduce all experimental conditions. Each experiment ran for two weeks. Five aquaria $(45 \times 40 \mathrm{~cm})$ were set up, each held five mussels (of known weight) of each of the six mussel size classes scattered over the bottom. Five seastars of a size class (i.e. $56-75 \mathrm{~mm}$ or $76-95 \mathrm{~mm}$ ) were placed individually in each. An automated lighting system illuminated the aquaria for $12 \mathrm{~h}$ each day. At least once every $24 \mathrm{~h}$ each aquarium was examined and any empty shells were weighed and replaced by a mussel of the same size class to maintain prey availability. At the end of each week all mussels were replaced with freshly collected ones.

\section{RESULTS}

\section{Handling Time}

A significant difference between the handling times of the various mussel size classes was obtained when all seastar sizes were combined $(\mathrm{F}=15.594 ; \mathrm{df}=4 / 15 ; \mathrm{p}<0.001)$ (fig. 1). The resultant variance was shown to increase exponentially with an increase in mussel size. Thus, the natural $\log (\ln )$ of $T h$ was calculated and plotted against mussel size, giving a linear relationship $\left(r^{2}=0.732, F=54.613, d f=1 / 20\right.$, $\mathrm{p}=0.0001$; fig. 2 ). Predictions of prey value were calculated from this relationship.

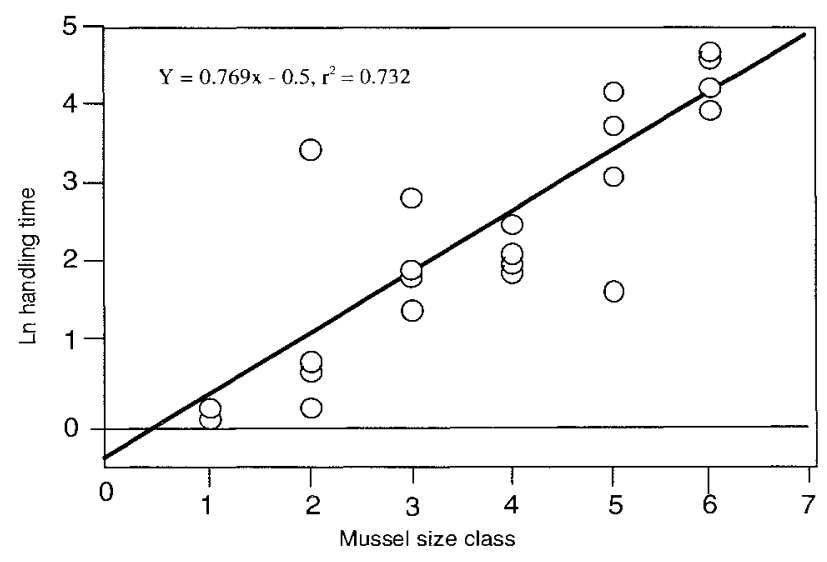

FIG. 2 - Relationship between the natural $\log (\mathrm{ln})$ of $\mathrm{Th}$ for Asterias amurensis feeding on six mussel size classes (where $1=<10 \mathrm{~mm} ; 2=10-19 \mathrm{~mm} ; 3=20-29 \mathrm{~mm}$; $4=30-39 \mathrm{~mm} ; 5=40-49 \mathrm{~mm} ; 6=50-59 \mathrm{~mm})$. 


\section{Mussel Energy Content and Prey Value}

The energy contents of the six mussel size classes (table 1) were not shown to be significantly different (single factor ANOVA; $F=2.55 ; \mathrm{df}=5 / 24 ; \mathrm{p}=0.055)$. Therefore, the energy content (kilojoules per gram of ash-free dry weight) of all the mussel size classes were averaged before prey value was calculated.

The average mussel energy content $\left(19.09 \mathrm{KJg}^{-1}\right)$ was multiplied by the average dry weight of each mussel size class, then divided by each respective handling time (calculated from the natural log regression) to give a prey value of seven mussel size classes (fig. 3). The optimal mussel size class (i.e. mussel size class of greatest prey value) was found to be $30-39 \mathrm{~mm}$.

\section{Size Selectivity}

The size range and number of mussels consumed by the seastars $(n=10)$ is shown in figure 4. ANOVA revealed that the preference for different mussel size classes was significantly different $(\mathrm{F}=4.080 ; \mathrm{df}=6 / 63 ; \mathrm{p}=0.002)$. $\mathrm{t}$-tests revealed that mussels of $20-29 \mathrm{~mm}$ were shown to be significantly preferred to those of the size classes $<10 \mathrm{~mm}(\mathrm{p}=0.028), 40$ $49 \mathrm{~mm}(\mathrm{p}=0.004), 50-59 \mathrm{~mm}(\mathrm{p}=0.003)$ and $60-69 \mathrm{~mm}$ ( $\mathrm{p}=0.001$ ) but not significantly preferred over the size classes $10-19 \mathrm{~mm}(\mathrm{p}=0.914)$ or $30-39 \mathrm{~mm}(\mathrm{p}=0.055)$.

\section{Preferred vs Optimal Mussel Size Class}

The combined data of mussels consumed by the two seastar size classes were compared to the calculated prey value for each mussel size class (fig. 5). A. amurensis was found to prefer the mussel of a size $20-29 \mathrm{~mm}$; a size class smaller than the calculated optimal mussel size class, $30-39 \mathrm{~mm}$. Thus, these results suggest that $A$. amurensis did not feed optimally.

\section{Feeding Rates}

The data collected allowed calculations of feeding rates of the two original seastar size classes to be made. These results are listed in table 2.

Both size classes consumed on average approximately one mussel per day. The larger seastars consumed marginally more mussel flesh per day than did the smaller ones. However, the smaller seastars consumed closer to double the percentage of their body weights per day $(4.97 \%$ vs $2.57 \%$ ) than did the larger seastars.

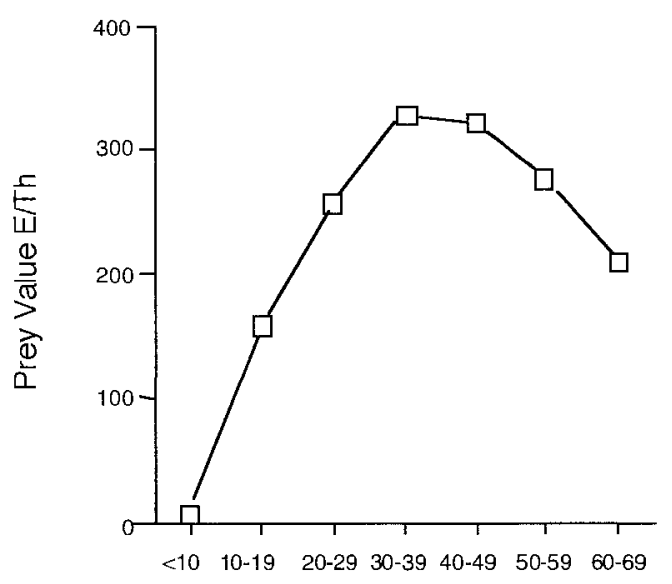

Mussel Size Class (mm)

FIG. 3 - Calculated prey value (E/Th) of seven mussel size classes for Asterias amurensis. (N.B. prey value was estimated for an extra mussel size class from the linear regression of $\ln$ handling time and mussel size).

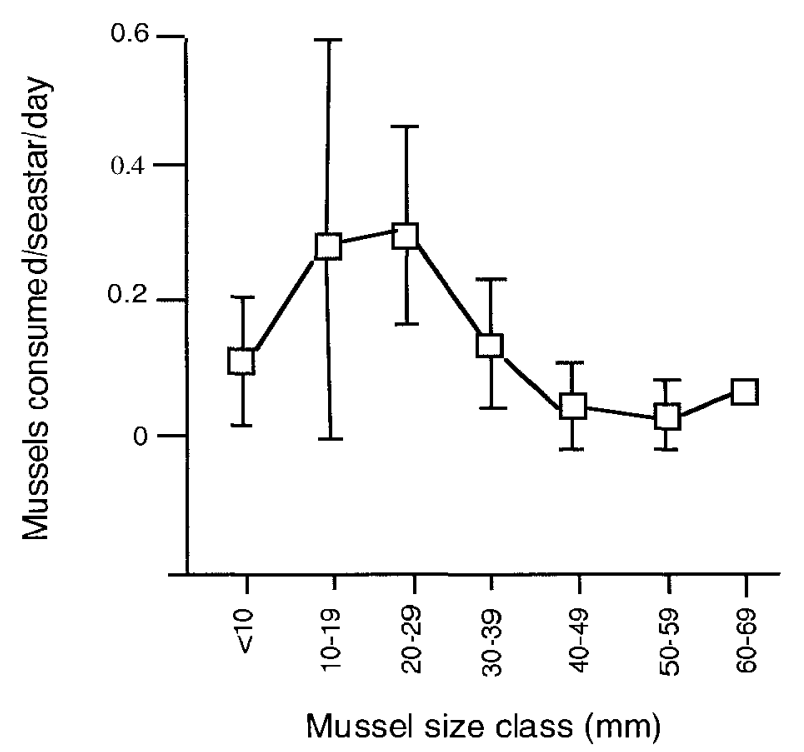

FIG. 4-Number of mussels consumed per seastar per day.

TABLE 1

Energy content* of seven Mytilus edulis size classes

\begin{tabular}{|c|c|c|c|c|c|c|c|}
\hline Mussel size class (mm) & $<10$ & $10-19$ & $20-29$ & $30-39$ & $40-49$ & $50-59$ & $60-69$ \\
\hline Energy content $\left(\mathrm{KJg}^{-1)}\right.$ & $12.61 \pm 2.65$ & $21.96 \pm 2.19$ & $19.72 \pm 2.35$ & $14.98 \pm 5.21$ & $17.35 \pm 2.09$ & $21.17 \pm 1.94$ & $19.39 \pm 1.78$ \\
\hline
\end{tabular}

${ }^{*} \mathrm{KJg}^{-1}$ of dry weight. 
TABLE 2

Feeding rates of two size classes of Asterias amurensis on Mytilus edulis

\begin{tabular}{lccc}
$\begin{array}{l}\text { Seastar } \\
\text { size } \\
\text { class }\end{array}$ & $\begin{array}{c}\text { Average } \\
\text { consumed/ } \\
\text { star/day }(\mathrm{g})\end{array}$ & $\begin{array}{c}\text { Average } \\
\text { number } \\
\text { consumed/ } \\
\text { star/day }\end{array}$ & $\begin{array}{c}\text { Average } \\
\text { body weight } \\
\text { consumed/ } \\
\text { star/day }\end{array}$ \\
\hline Small & $1.39 \pm 0.49$ & 0.80 & $4.97 \pm 2.37$ \\
Large & $1.48 \pm 0.62$ & 0.87 & $2.57 \pm 1.44$
\end{tabular}

\section{DISCUSSION}

Despite efforts to standardise hunger levels, the time taken by $A$.amurensis to handle and consume Mytilus edulis varied considerably amongst seastars of the same size, which has also been observed for $A$. rubens by Allen (1983). The mussel size classes, as explained, were presented to each of the four seastars in random order, but unfortunately temporal constraints prevented standardisation of digestive pauses (Galtsoff \& Loosanoff 1939) between each mussel consumed. The long periods of time needed to consume one prey item also make larger numbers of replicates desirable than were possible in the present study. Furthermore, the possibility that some of the seastars may have benefited from previous experience with mussels prior to capture cannot be ruled out.

Asteroids feed on mussels by using a combination of a pulling force exerted by the tube feet and inserting the very thin stomach folds into gaps as small as $0.1 \mathrm{~mm}$ wide (Binyon 1972, Jangoux 1982). Gaps exist naturally in most bivalves even when closed, usually where the byssus threads emerge (Feder 1955). Th was found to increase exponentially with increase in mussel size. Shaw (1988) found that the handling time of Coscinasterias calamaria also increased exponentially with increase in mussel size. The long $T h$ and the variation of $T h$ between seastars in the present study could have been due to their reproductive status, since the present experiments were conducted within the spawning period of $A$. amurensis in Tasmania (Morrice 1995).

The many video-taped hours in the current investigation allowed for some interesting observations on the handling of mussels by $A$. amurensis. The seastars generally sensed the mussels immediately after they had been placed in the aquaria; evidenced by the curling of the arm tip closest to the mussel and the extension and waving of the terminal or sensory tube feet of the same arm tip (Sloan 1980). The seastars immediately proceeded to crawl on top of the mussel and spent anywhere from $1.5 \mathrm{~min}$ to $2.5 \mathrm{~h}$ (with an average of $14 \mathrm{~min}$ ) in orientating the mussel (To). During this time the seastar rotated, presumably exploring the mussel for weaknesses or gaps and the best position to begin opening it. After this time, the seastars remained still, attempting to open the mussel, for long periods. However, the feeding time (Tf) was interspersed with periods during which the seastar would move position, sometimes attacking the mussel from the side instead of from above in the characteristic humped posture. In addition, the seastars occasionally abandoned the mussel for periods, or moved up and around the walls of the

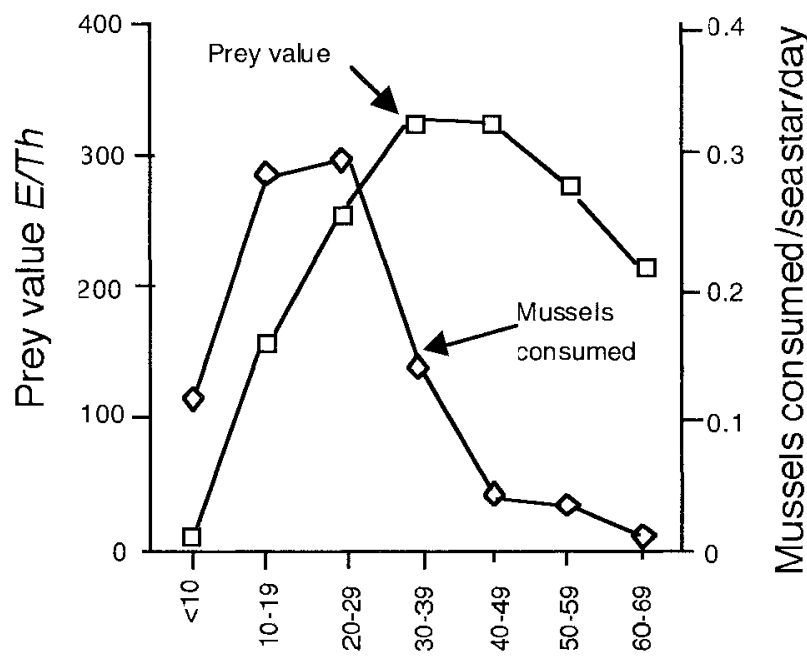

Mussel size class $(\mathrm{mm})$

FIG. 5 - Prey value (E/Th) of seven mussel size classes compared to those mussels consumed per seastar per day.

aquaria with the mussel held at the oral region by the buccal tube feet or dragged behind, attached by only a few tube feet. Even though some seastars remained on a mussel until digestion of the flesh and adductor muscle was complete, it does not necessarily mean they fed continuously. The original time spent in orientating the mussel, the frequency and duration of further orientating periods or the frequency and duration of time spent moving around the aquarium, with or without the mussel, did not seem at all related to the size of the mussel or to the size of the seastar. These periods are probably more closely related to the satiation level or the nutritional requirements of individual seastars and may be an interesting topic for research. The ability of the seastars to travel with prey items may be adaptive in several ways: it may enable $A$. amurensis to move a prey item away from the intertidal zone, to prevent exposure, or from other areas with unfavourable conditions, while feeding; it may serve to avoid conspecifics "stealing" prey items; and/or it may provide a means for temporarily "storing" prey items until hunger reaches a level when the seastar needs to feed again, due to the need for a digestive pause (Galtsoff \& Loosanoff 1939, Holling 1965 in Norberg 1977, pers. obs.).

A. amurensis was shown to prefer mussels of a size between 20 and $29 \mathrm{~mm}$ in length; a much smaller size class than the mean size available. A number of asteroids (Christensen 1970, Penney \& Griffiths 1984, Fukuyama \& Oliver 1985, Beddingfield \& McClintock 1993) and indeed crustaceans such as crabs (Elner \& Hughes 1978) and lobsters (Robles et al. 1990) are known to select prey of smaller sizes than the mean size available. For example, Astropecten spp. select small and juvenile bivalves although, unlike Asterias amurensis, they feed intraorally and kill their prey by anoxia (Christensen 1970, Beddingfield \& McClintock 1993).

The fitness of a foraging animal is a function of the efficiency of foraging measured in terms of some "currency", usually energy (Pyke et al. 1977). Many studies have shown that animals select prey of high profitability, which includes optimal prey sizes. Feder \& Christensen (1967 in O'Neill et al. 1983) explained that, as bivalve size relative to the 
seastar size increases, the efficiency of the force exerted to open the prey becomes limiting. Also, large seastars feeding on very small prey will not be effectively utilising the full digestive capabilities of the stomach. $A$. amurensis did not prefer the size class of $M$. edulis that was calculated as being the greatest value as prey: $30-39 \mathrm{~mm}$. Selecting smaller mussels may be a way of avoiding direct competition from conspecifics since they can be consumed in a shorter period of time. However, the size class 20-29 $\mathrm{mm}$ was not significantly preferred over "suboptimal" mussel size classes. $A$. amurensis was also expected to be capable of assessing the value of a prey item and to consume those items which would give the greatest energy return for the energy expended in handling the prey, thus maximising its energy intake. Elner \& Hughes (1978) observed that the crabs manipulated prey in their chelae before accepting or rejecting, thereby making an active choice. $A$. amurensis also appeared to make an active choice. Each seastar often travelled around the tank and over the mussels, occasionally stopping to adopt a humped posture before moving on and finally consuming a mussel. However, the $20-29 \mathrm{~mm}$ mussel size class was not significantly preferred over the optimal size class (i.e. $30-39 \mathrm{~mm}$ ).

An alternative hypothesis could be that there was a variation in the nutritional status of the mussels; both those used to measure $T h$ and those used to establish size selectivity. The sex, reproductive status and the presence of pea crabs, Pinnotheres hickmani, could all vary the nutritional value of the mussels. Also, ingestive conditioning may be involved, whereby handling of specific prey types and sizes are improved with experience. This leads to an increase in the prey value (Hughes 1980).

Size selectivity is dependent on the prey to predator ratio and, thus, optimal prey sizes are expected to increase with an increase in predator size. The long handling times, resulting in few replicates, meant that this could not be fully examined in the present study. However, an increase in the size of prey selected with an increase in the size of the predator has been shown in a number of other studies, such as for the asteroid $A$. vulgaris (O'Neill et al. 1983) and the lobster Panulirus interruptus (Robles et al. 1990). Kim (1969) found that $A$. arnurensis in Japan, of similar sizes to those used in the present study, preferred $M$. edulis of 20 $40 \mathrm{~mm}$ in length, and the largest mussels consumed were, on average, 0.7 times the seastars' radius. However, these seastars were capable of consuming $M$. edulis that were equal in length to the radius of the seastars. These results are virtually the same as those found for the Tasmanian population of $A$. amurensis in the present study.

The significance of size selective feeding is thought to be that predator and prey can coexist because the surviving large prey may make a reproductive contribution that is disproportionately greater than their abundance (Paine 1976). However, aggregations of $A$. amurensis can lead to sharing of prey items so that large prey sizes, which could not normally be consumed by individuals, can be consumed by cooperation with conspecifics (Lockhart \& Ritz, pers. obs.). Regardless, few mussels larger than the largest consumed by the seastars in the present study $(60-69 \mathrm{~mm})$ could be found on the Derwent Sailing Squadron wharfs. Thus, coexistence of $A$. amurensis and this native prey species by reaching a size refuge is, although possible, not as likely as that found by Paine (1976) with Pisaster ochraceus and its prey, $M$. californianus. Nevertheless, spatial refuges for prey are possible in the high intertidal zone, on moorings and other areas which are not easily accessible to $A$. amurensis. Through size selective feeding by $A$. amurensis, shown in the present investigation, this predator may affect the age structure of prey populations by foraging intensively on intermediate sizes. This could result in maintenance of a bimodal distribution in some prey populations as this species is believed to do in Norton Sound, Alaska (Fukuyama \& Oliver 1985).

In the present study, $A$. amurensis of the smaller size class was shown to consume $M$. edulis at the daily rate of $4.97 \%$ of wet body weight and the larger seastars consumed $2.57 \%$. A number of studies on asteroids have included feeding rates on mussels. Feder (1970) found that $P$. ochraceus, a well-known voracious predator, consumed mussels at a daily rate of $1.1 \%$ of their wet body weight in the late winter to early spring. As in the present investigation, smaller $P$. ochraceus were shown to consume much more than their larger conspecifics, at 6-11\% (Feder 1970). O'Neill et al. (1983) also found that smaller $A$. vulgaris consumed a greater percentage of their body weights than did larger conspecifics. On average, Feder (1970) and Hancock (pers. comm. in Feder 1970) found that $P$. ochraceus and $A$. rubens respectively consumed no more than $3 \%$ of their wet weight per day, which approximates the results found here for $A$, amurensis. Feeding rates of $C$. muricata are of particular interest, as this species is likely to be a competitor of $A$. amurensis in Tasmania as it preys on many of the same species. Bell (1977) found that C. muricata consumed 0.25 mussels per seastar per day, which is much less than that found for $A$. amurensis. However, it was calculated that $C$. muricata consumed from 3.9 to $5.1 \%$ of their wet weight per day, which is similar to the results of the present study. Hatanaka \& Kosaka (1959) calculated that $A$. amurensis in Japan could consume $193 \mathrm{~g}$ of soft bivalve parts per seastar per year. On the basis of the results presented here it is estimated that $A$. amurensis in Tasmania could potentially consume on average 515 g per seastar per year.

\section{ACKNOWLEDGEMENTS}

This research was supported by a scholarship provided by the Seastar Task Force. We thank Liz Turner of the Tasmanian Museum for her advice. We also appreciate the advice and information provided by Margie Morrice, Kevin Grannum, Nick Murfett and two referees.

\section{REFERENCES}

Allen, P.L., 1983: Feeding behaviour of Asterias rubens (L.) on soft bottom bivalves: a study in selective predation. $J$. Exp. Mar. Biol. Ecol 70: 79-90.

Beddingfield, S.D. \& McClintock, J.B., 1993: Feeding behaviour of the seastar Astropecten articulatus (Echinodermata: Asteroidea): an evaluation of energyefficient foraging in a soft-bottom predator. Mar. Biol. 115: 669-676

BELL, R.S., 1977: FEEDING BIOLOGY OF THE STARFISH COSCINASTERIAS CALAMARIA (GRAY, 1840). University of Tasmania, Tasmania.

BINYON, J., 1972: PHYSIOLOGY OF ECHINODERMS. Pergamon Press, Oxford: 264 pp. 
Byrne, M., Morrice, M.G. \& Wolf, B. 1997: Introduction of the northern Pacific asteroid Asterias amurensis to Tasmania: reproduction and current distribution. Mar. Biol. 127: 673-685.

Buttermore, R.E., Turner, E. \& Morrice, M.G., 1994: The introduced Northern Pacific seastar Asterias amurensis in Tasmania. Mem. Qld Mus. 36: 21-25.

Christensen, A.M., 1970: Feeding biology of the sea-star Astropecten irregularis Pennant. Ophelia 8: 1-134.

Doering, P.H., 1981: Observations on the behaviour of Asterias forbesi feeding on Mercenaria mercenaria. Ophelia 20: 169-177.

ELNER, R.W. \& Hughes, R.N., 1978: Energy maximization in the diet of the shore crab, Carcinus maenas. J. Anim. Ecol. 47: 103-116.

Feder, H.M., 1955: On the methods used by the starfish Pisaster ochraceus in opening three types of bivalve molluses. Ecology 36: 764-767.

FEDER, H.M., 1970: Growth and predation by the ochre seastar, Pisater ochraceus (Brandt), in Monterey Bay, California. Ophelia 8: 161-185.

Fukuyama, A.K. \& Oliver, J.S., 1985: Seastar and walrus predation on bivalves in Norton Sound, Bering Sea, Alaska. Ophelia 24: 17-36.

Galtsoff, P.S. \& Loosanoff, V.L., 1939: Natural history and method of controlling the starfish (Asterias forbesi, Desor). Bull. US Bur. Fish. 49: 75-132.

Hatanaka, M. \& Kosaka, M., 1959: Biological studies on the population of the starfish, Asterias amurensis in Sendai Bay. Tohoku J. Agric. Res. 9: 159-173.

HugheS, R.N., 1980: Optimal foraging theory in the marine context. Oceanogr. Mar. Biol. Ann. Rev. 18: 423-481.

JANGOUX, M., 1982: Food and Feeding Mechanisms: Asteroidea. In Jangoux, M. \& Lawrence, J.M. (Eds): ECHINODERM NUTRITION. A.A. Balkema, Rotterdam.

KIM, Y. S., 1969: Selective feeding on the several bivalve molluscs by starfish, Asterias amurensis Lutken. Bull. Fac. Fish. Hokkaido Univ. 19: 244-249.

Landenberger, D. E., 1968: Studies on selective feeding in the pacific starfish Pisaster in southern California. Ecology 49: $1062-1075$.

MCCuntock, J. B. \& LaWrence, J. M., 1981: An optimization study on the feeding behaviour of Luidia clathrata Say (Echinodermata: Asteroidea). Mar. Behav. Physiol. 7: 263275

MCCuntock, J. B. \& Lawrence, J. M., 1985: Characteristics of foraging in the soft-bottom benthic starfish Luidia clathrata (Echinodermata: Asteroidea): prey selectivity, switching behaviour, functional responses and movement patterns. Oecologia 66: 291-298.

MenGE, B.A., 1972: Competition for food between two intertidal starfish species and its effects on body size and feeding. Ecology 53: 635-644

MORRICE, M.G., 1995: THE DISTRIBUTION AND ECOLOGY OF THE INTRODUCED NORTHERN PACIFIC SEASTAR, ASTERIAS AMURENSIS (LÜTKEN) IN SOUTH-EASTERN TASMANIA. Australian Nature Conservation Agency, Canberra.

NorberG, R.A., 1977: An ecological theory on foraging time and energetics and choice of optimal food- searching method. J. Anim. Ecol. 46: 511-529.

O'Neill, S.M., Sutterlin, A.M. \& Aggett, D., 1983: The effects of size-selective feeding by starfish (Asterias vulgaris) on the production of mussels (Mytilus edulis) cultured on nets. Aquaculture 35: 211-220.

Paine, R.T., 1976: Size-limited predation: an observational and experimental approach with the Mytilus-Pisaster interaction. Ecology 57: 858-873.

Paul, A.J. \& Feder, H.M., 1975: The food of the seastar Pycnopodia helianthoides (Brandt) in Prince William Sound, Alaska. Ophelia 14: 15-22.

Penney, A.J. \& Griffiths, C.L., 1984: Prey selection and the impact of the starfish Marthasterias glacialis (L.) and other predators on the mussel Choromytilus meridionalis (Krauss). J. Exp. Mar. Biol. Ecol. 75: 19-36.

Pyke, G.H., Pulliam, H.R. \& Charnov, E.L., 1977: Optimal foraging: A selective review of theory and tests. Quart. Rev. Biol. 52: 137-154.

Robles, C., SWeETNAM, D. \& EMINIKE, J., 1990: Lobster predation on mussels: shore-level differences in prey vulnerability and predator preference. Ecology 71: 1564-1577.

SHAW, C., 1988: OPTIMAL FORAGING THEORYAS APPLIED TO THE FEEDING BEHAVIOUR OF THE ASTEROID COSCINASTERIAS CALAMARIA(GRAY) ON MYTILUS EDULIS L. IN PORT PHILLIP BAY, VICTORIA. University of Melbourne, Victoria.

SLOAN, N. A., 1980: The arm curling and terminal tube-foot responses of the asteroid Crossaster papposus. J. Nat. Hist. 14: 469-482.

Turner, E., 1992: A northern Pacific seastar, Asterias amurensis, in Tasmania. AMSA Bull. 120: 18-19.

(accepted 25 June 2001) 